\title{
Influence of aging on deterioration of patients with COVID-19
}

Review

\author{
Limin Pang ${ }^{1, *}$, Yi Liu ${ }^{1, *}$, Maoze Shen ${ }^{4, *}$, Jujian $\mathrm{Ye}^{1}$, Ruirong Chen ${ }^{1}$, Zhien Lan ${ }^{1}$, Zhijian $\mathrm{Wu}^{3}$, \\ Yang Guo ${ }^{2}$, Peidong Zhang ${ }^{1}$
}

${ }^{1}$ Department of Cardiology, Heart Center, Zhujiang Hospital, Southern Medical University, Guangzhou, Guangdong, People's Republic of China

${ }^{2}$ Department of Neurology, Zhujiang Hospital, Southern Medical University, Guangzhou, Guangdong, People's

Republic of China

${ }^{3}$ Department of Cardiology, Boai Hospital of Zhongshan, Southern Medical University, Zhongshan, People's

Republic of China

${ }^{4}$ Department of Internal Medicine, Raoping County People's Hospital, Chaozhou, Guangdong, People's Republic of China

*Equal contribution

Correspondence to: Peidong Zhang, Yang Guo, Zhijian Wu; email: zhangpd@smu.edu.cn; guoyangmed@126.com, https://orcid.org/0000-0001-9814-8123; 2388743877@qq.com, https://orcid.org/0000-0001-8212-2631

Keywords: aging, COVID-19, GRP78, ACE2, CD147

Received: August 12, $2020 \quad$ Accepted: September 29, 2020

Published: November 24, 2020

Copyright: $(2020$ Pang et al. This is an open access article distributed under the terms of the Creative Commons Attribution License (CC BY 3.0), which permits unrestricted use, distribution, and reproduction in any medium, provided the original author and source are credited.

\section{ABSTRACT}

Aging is an important factor affecting the deterioration of patients with coronavirus disease 2019 (COVID-19). The aging and degeneration of various tissues and organs in the elderly lead to impaired organ function. Underlying conditions such as chronic lung disease, cardiovascular disease, and diabetes in aged patients are associated with higher mortality. Severe acute respiratory syndrome coronavirus 2 (SARS-CoV-2) primarily interacts with the cell surface receptor angiotensin-converting enzyme (ACE) 2 and other accessory proteins such as 78 kDa glucoseregulated protein 78 (GRP78) and CD147. Thus, altered receptor signals in aging and chronic disease play a role in SARS-CoV-2 infection, and are associated with a higher risk of deterioration in different organs. In this review, after a brief introduction to the link between aging and receptors for SARS-CoV-2, we focus on the risk of deterioration in different organs of COVID-19 patients considering aging as the main factor. We further discuss the structural and/or physiological changes in the immune system and organs (lung, heart, kidney, vessels, nerve system), as well as those associated with diabetes, in aging patients, and speculate on the most likely mechanisms underlying the deterioration of COVID-19 patients.

\section{INTRODUCTION}

Biological aging in humans is characterized by genomic instability, telomere attrition, epigenetic alterations, loss of proteostasis, dysregulated nutrient sensing, mitochondrial dysfunction, cellular senescence, stem cell exhaustion, and altered intercellular communication. These abnormal changes in the body lead to age-related damage $[1,2]$. The accumulation of aging-related damage leads to increased morbidity and mortality among the elderly [3]. Aging lowers the human body's resistance to pathogens and impairs the subsequent immune responses. In the case of severe acute respiratory syndrome coronavirus 2 (SARS-CoV2) pneumonia, the damages caused by human aging are closely related to the deterioration of the condition of the patients. Aging adults are more likely to have underlying comorbidities and are therefore at greater risk of deterioration of coronavirus disease-2019 (COVID-19) [4]. In Figure 1, we have summarized 
the association between COVID-19 and aging in various organs.

\section{The ongoing age-related COVID-19 pandemic}

Following the initial reports of COVID-19 in December 2019 , this disease rapidly became a pandemic and a major global public health concern. COVID-19 is an infectious disease caused by SARS-CoV-2. From a global perspective, the situation remains bleak as this pandemic has concentrated medical attention on treating people with COVID-19. There is a widespread lack of immunity to this emerging pathogen, and the world's population is largely susceptible to this virus. Epidemiological studies have shown that COVID-19 is less common in children than in older adults, especially those with underlying comorbidities. Moreover, middleaged and elderly people are the most affected by this disease, while elderly patients and those with underlying diseases have more acute and shorter courses of the disease [5-13]. We integrated the data from several reports and found that the ratio of deaths to infections was higher in the elderly than in the other age groups (Figure 2). Comorbidities, including chronic lung disease, cardiovascular disease, chronic kidney disease (CKD), and diabetes, are also associated with higher mortality in older patients $[9,14,15]$.

\section{The link between virus receptors and aging}

SARS-CoV-2 belongs to the same beta coronavirus subgroup that also comprises severe acute respiratory syndrome coronavirus (SARS-CoV) and Middle East respiratory syndrome coronavirus (MARS-CoV). Viruses in this group have an affinity for angiotensinconverting enzyme 2 (ACE2) and the auxiliary molecule, transmembrane serine protease (TMPRSS2) [16-18]. Studies have shown that SARS-CoV-2 invades the human body via the ACE2 receptor. Moreover, the affinity of SARS-CoV-2 for ACE2 is ten-fold higher than that of SARS-CoV. The receptor-binding domain (RBD) of the S1 subunit of the viral Spike protein binds to ACE2 to invade target cells [19-21]. In coronavirus infection, ACE2 bound by the coronavirus will be cleaved by a disintegrin and metalloprotease 17 (ADAM17, also called TNF- $\alpha$ converting enzyme, TACE), thereby reducing the concentration of ACE2 at the cell surface [22]. Studies have shown that the overall expression of ACE2 in the human body is ageand tissue-dependent. The concentration of ACE2, as
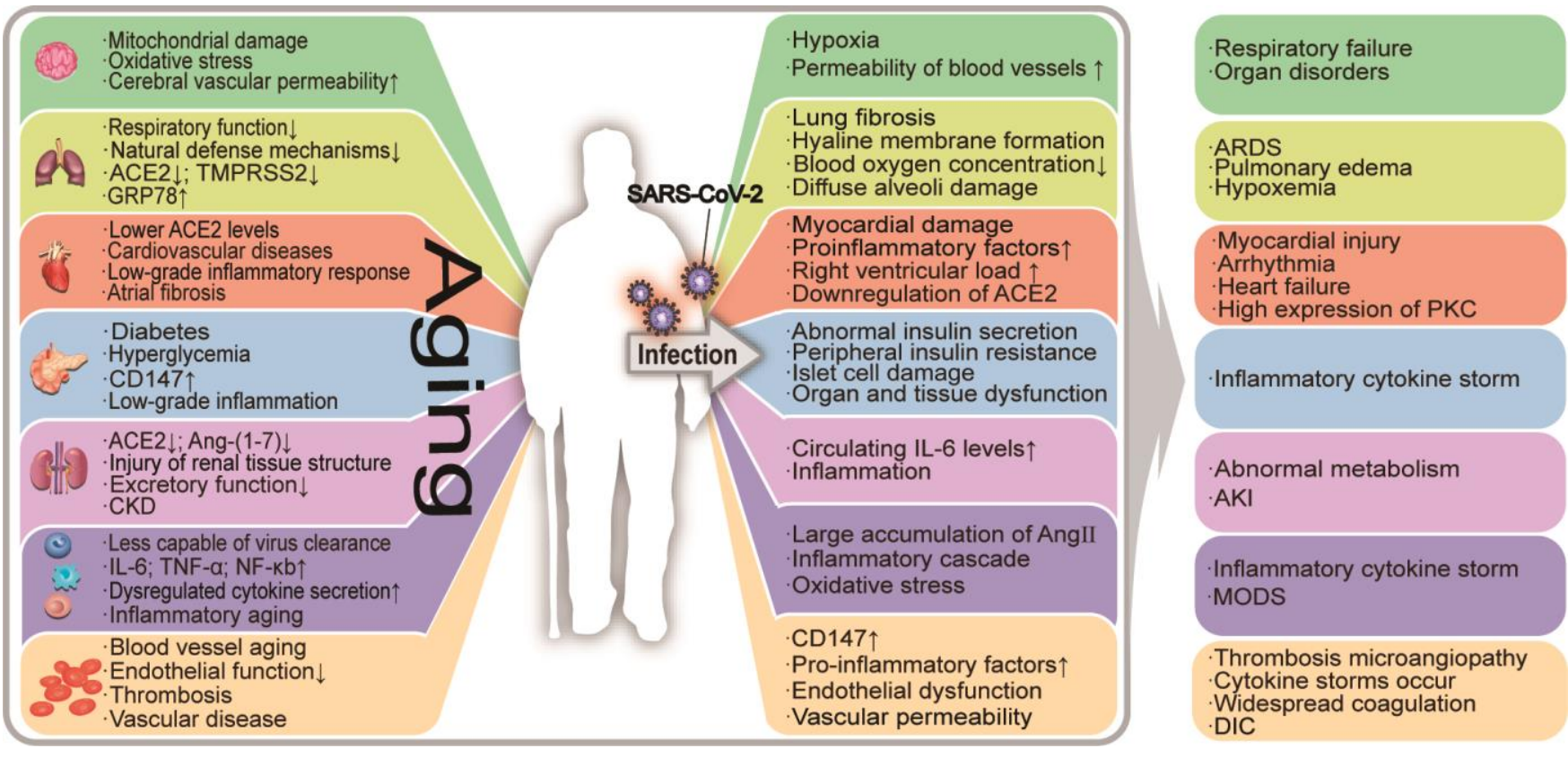

Figure 1. The effects of aging on the organism and its relationship with COVID-19-associated deterioration. Aging patients are more susceptible to SARS-CoV-2, which leads to the exacerbation of COVID-19. Aging has a negative impact on the human organ system, causing its functional decline. The aging process is accompanied by a state of low-grade inflammation, and the elderly are more susceptible to SARS-CoV-2 infection. Under the influence of the virus, the damage to infected aging patients is further worsened, resulting in serious secondary diseases. In the figure, "个" means the number increases, the function or effect is enhanced; " $\downarrow$ " means the number decreases, the function or effect is weakened. ERS: endoplasmic reticulum stress; ACE2: angiotensin-converting enzyme 2; TMPRSS2: transmembrane protease serine 2; ADAM17: a disintegrin and metalloprotease 17; ARDS: acute respiratory distress syndrome; AKI: acute kidney injury; PKC: protein kinase C; ROS: reactive oxygen species; CKD: chronic kidney disease; DIC: disseminated intravascular coagulation. 
well as that of other receptors associated with SARSCoV-2 infection, is higher in adults than in children [23], which may result in a higher rate of infection. However, ACE2 expression in cells of pulmonary, renal, and cardiovascular tissue has been demonstrated to decline with age [24-26]. The function of ACE2 is to convert angiotensin (Ang) II into Ang-(1-7) and increase the level of superoxide dismutase (SOD), which can reduce cell peroxidation-related damage [27, 28]. Ang-(1-7) can reduce Ang II concentrations and antagonize its activity. Meanwhile, plasma ACE2 activity reportedly increases with age [29], which can increase production of Ang-(1-7). ACE2 shedding through ADAM17mediated cleavage may be associated with increasing Ang II levels, as well as the modulation of the reninangiotensin system (RAS) in cardiovascular and chronic diseases [30-32].

Recent evidence has suggested that SARS-CoV-2 can also bind to CD147 and $78-\mathrm{kDa}$ glucose-regulated protein (GRP78) expressed on the cell surface [33, 34]; the levels and functions of both proteins may also be related to aging. Blocking CD147 has an inhibitory effect on SARS-CoV-2, suggesting that CD147 may promote SARS-CoV-2 invasion [35, 36]. The levels of
CD147, known as a key target for malaria treatment, can increase with age, thereby also increasing the number of targets for invasion by the virus [37, 38]. Cell surfacelocalized GRP78 mediates endoplasmic reticulum stress (ERS) and can help to activate transcription factors and maintain cell homeostasis. Because viral infection and nutrition deprivation can stimulate the ERS-associated unfolded protein response (UPR) [39], SARS-CoV-2 infection will likely lead to increased GRP78 concentrations, as recently reported [40]. However, GRP78 expression can decrease with aging, thereby lowering the ability of the endoplasmic reticulum to clear misfolded proteins, which is associated with poor prognosis in older COVID-19 patients [41].

\section{The aging immune system and low-grade inflammation}

In the elderly, COVID-19 is more likely to lead to complications, including the outbreak of a "cytokine storm", acute respiratory distress syndrome (ARDS), multiple organ dysfunction syndrome (MODS), and eventually even death. Deceased patients typically display a sustained increase in interleukin (IL)-6, Ddimer, lactate dehydrogenase, and serum ferritin levels

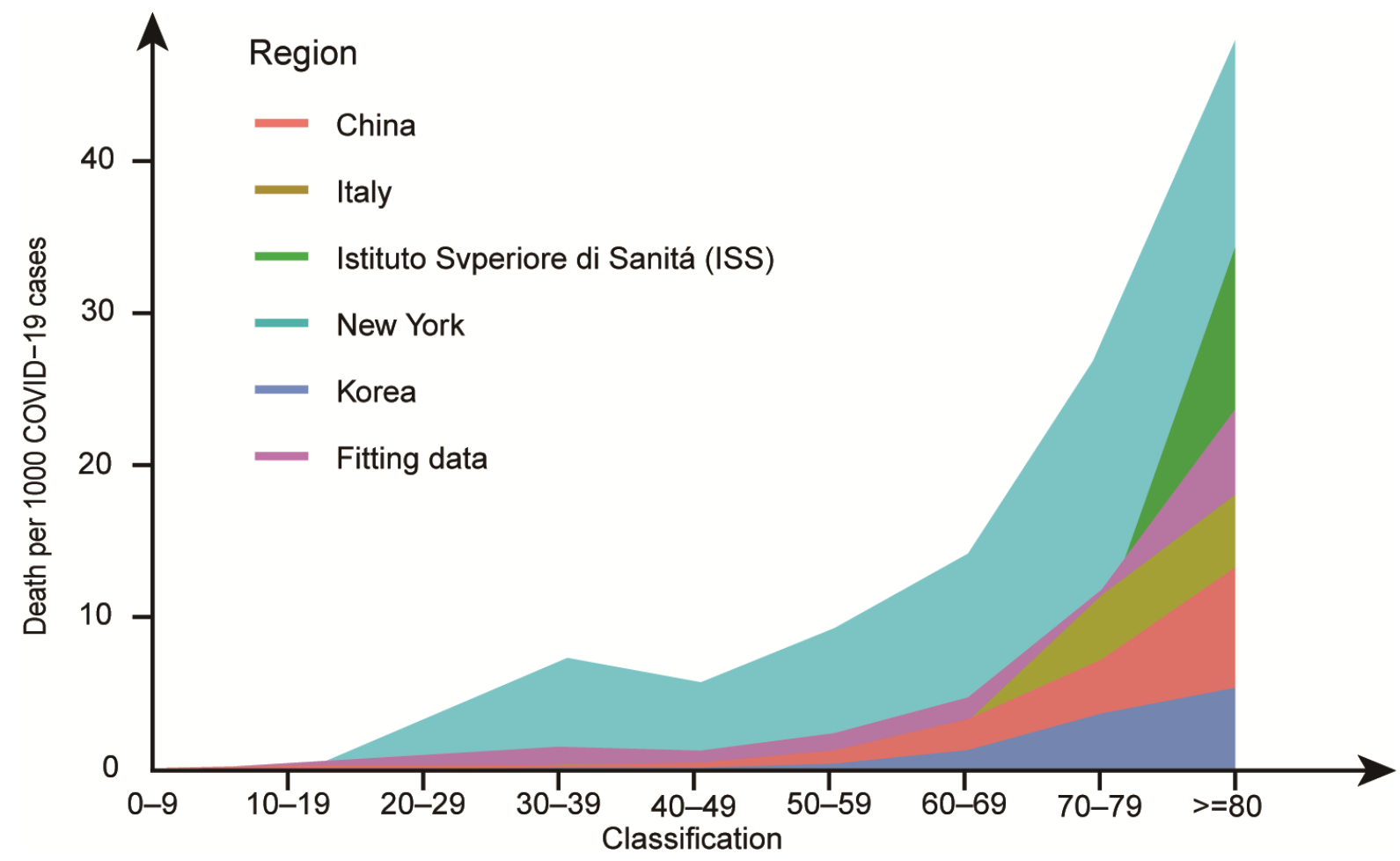

Figure 2. Deaths per 1,000 COVID-19 cases by age group in major epidemic areas. Data from references [6, 101-104] have been amalgamated with the above data to fit the new data. After standardizing the data for each group, the probability of death at each age was fitted and multiplied by 1,000. The ggplot2 package in R version 4.0.0 was used to draw a line graph. Marine green represents New York, red represents China, blue represents South Korea, yellow represents Italy, grass green represents ISS, and purple represents the fitting data. In the line graph, the number of deaths per 1,000 COVID-19 patients increases with age. 
$[14,42]$, suggesting that patients suffer severe inflammation and pathological damage before the end of life.

An aging immune system is less capable of virus clearance. Thymus glands, the spleen, and lymph nodes undergo degeneration in aging, which interferes with the normal differentiation of $\mathrm{T}$ cells, phagocyte viability, and the secretion of natural killer (NK) cells $[43,44]$. In the elderly, an aging immune system leads to poor recognition and elimination of viruses and cancer cells and an overall decline in the immune response of normal cells [45].

Cytokine storms are more likely to occur in the elderly. According to the theory of immunologic dissonance, the imbalance of pro-inflammatory and anti-inflammatory forces in the elderly leads to destructive immune dysregulation [46, 47]. Reduced ACE2 expression during aging increases ovalbumin-induced eosinophil, lymphocyte, and neutrophil recruitment [48] and leads to dysregulated cytokine secretion, which ultimately results in damage to various organs. On the one hand, owing to the immaturity of the proliferative pool, the absolute number of neutrophils is significantly lower in newborns than in adults. This is manifested by the high expression of adhesion molecules (e.g., P-selectin) and the increased chemokine production by resident inflammatory cells [49], decreased reactivity, and increased extravasation. On the other hand, the absolute number of neutrophils is thought to be related to aging. Aging leads to increased expression of IL- 6 and TNF- $\alpha$ in the body, which aggravates the inflammatory response [50], and can also lead to the upregulation of nuclear factor-kappa B (NF- $\kappa \mathrm{B})$, the main regulator of IL-6 and IL-1 $\beta$, thereby altering the levels of these cytokines. Viral invasion aggravates inflammation, and inflammatory factors continue to accumulate while the body's immune system fails to clear these inflammatory factors in a timely manner [51]. The aging process is accompanied by a state of low-grade inflammation. The serum level of inflammatory mediators is significantly higher in the elderly than in the young. Low-grade inflammation can induce changes in several signaling pathways, and, importantly, can also lead to the deterioration of COVID-19 and age-related diseases $[52,53]$. One feature of chronic inflammation due to aging is a change in the Ang II signaling pathway. Factors downstream of Ang II, such as IL- 6 and TNF- $\alpha$, promote the occurrence and development of inflammation. After SARS-CoV-2 invades the human body, the downregulation of ACE2, when combined with aging, will cause a large accumulation of Ang II. Simultaneously, Ang II can integrate mechanisms such as reactive oxygen species (ROS) formation, leading to a vicious cycle of cellular aging [27].
An increase in the levels of Ang II disrupts the balance between ROS production and removal, which further intensifies oxidative stress [27]. ROS production through NOX2, a member of the NADPH oxidase (NOX) family of enzymes, has been demonstrated to play a key role in lung injury [54]. The ROS and hydrogen peroxide produced during oxidative stress can lead to tissue injury and irreversible damage to macromolecular proteins. ROS is indirectly responsible for the body's proinflammatory response and the accumulation of proinflammatory factors, which leads to a worsening of the overall condition and ultimately triggers cytokine storms and MODS.

\section{Lung aging and COVID-19}

One of the most obvious characteristics of COVID-19 infection is viral pneumonia. Out of a group of 1,591 patients, $88 \%$ needed respiratory support [10], similar to the results reported for another group of patients [55]. In another cohort comprising 1,099 cases, 3.4\% had ARDS and $>59 \%$ had abnormal pulmonary computed tomography (CT) findings [9]. The clinical features of ARDS, also known as acute respiratory failure (ARF), comprise altered respiratory system mechanics and hypoxemia. Middle-aged and elderly people are more likely to develop ARF and show a higher rate of intensive care unit (ICU) admittance than younger patients.

The effect of SARS-CoV-2 on ACE2 can easily reduce lung function in the elderly. Reduced ACE2 expression due to SARS-CoV-2 infection further reduces ACE2 in the lungs of the elderly, but without affecting ACE content $[22,56]$. Without ACE2, the conversion of Ang II into Ang-(1-7) is reduced, thereby allowing Ang-(17) to exert a protective effect against pulmonary edema, reduce pulmonary vascular resistance, resist tissue damage, and reduce myeloperoxidase content in the lungs [48]. High levels of Ang II hyperactivate the Ang II type 1 receptor (AT1R) in the lungs, contributing to the contraction of bronchial smooth muscle cells and increased pulmonary capillary permeability, resulting in a dry cough, pulmonary edema, and difficulty breathing [28]. The expression of GRP78 protein decreases with age, which affects lung tissue repair and aggravates viral infection-associated damage. In the aged lung, the GRP78 level decreases while ERS increases, which causes lung fibrosis [57]. Apoptosis occurs more readily in older patients than in younger ones under high levels of ERS induced by virus infection [58]. In SARSCoV-2 infection, abnormal apoptosis can disrupt the repair and remodeling of lung tissue and disturb endoplasmic reticulum homeostasis, which aggravates the irreversible damage to the lungs and leads to unfavorable prognosis. 
The respiratory function and natural defense mechanisms are lowered in the aging lung, which disrupts its ability to clear the virus and regulate hypoxic adaptation. The influence of advanced age on many aspects of lung immunity, including a series of structural and physiological changes to the lungs, is reflected in cell dysfunction and changes in innate immune system signals [59]. Studies have shown that many patients with severe COVID-19 present with basic pulmonary diseases. In the elderly, the lung is likely to develop an emphysema-like phenotype, which is also observed in chronic obstructive pulmonary disease (COPD) [60]. The effects of oxidative stress and mitochondrial DNA damage are obvious in the aging lung tissue, and lead to high levels of apoptosis in lung cells in COPD patients [61]. The severity of COVID-19 is markedly increased in COPD patients [9] and may suggest that an emphysema-like phenotype and other age-associated structural changes can exacerbate COVID-19. In patients aged $>60$ years, there is an evident decline in the functions of the respiratory immune barrier, especially alveolar phagocytosis, ventilation, tracheal epithelial ciliary movement, and cough reflex, resulting in poor virus clearance [59]. In terms of respiratory function, the contraction and relaxation of the diaphragm muscles, which are closely related to ventilatory activities, can help to relieve the symptoms of hypoxia that are associated with COVID19. However, the function of the diaphragm muscle is weakened with aging, resulting in abnormalities in excitation-contraction coupling, organizational structure, and metabolism [62]. Aged lungs have a reduced capacity to alleviate hypoxia. Respiration will be affected if the nerve center is infected with the virus, as will diaphragm function [63]. Osteoporosis in the elderly also influences the shape of the chest, limiting lung contraction [60].

A heightened inflammatory response in aging will exacerbate COVID-19. Ground-glass opacity (GGO) and bilateral lung plaque shadow are commonly seen in chest CT scans of COVID-19 patients. The scope of lesions expands with disease aggravation. The severe period can quickly progress to a wide range of diffuse pulmonary change, and pleural effusion, so the lungs show large white areas in CT images [64]. In autopsies of COVID-19 patients, the lungs showed diffuse alveoli damage and hyaline membrane formation, and a large number of viscous secretions overflowing from the alveolar cells, displaying the pathological characteristics of ARDS [34]. A severe inflammatory reaction in the lung is indicated by neutrophil accumulation, causing deconstruction and edema of the celiac capillaries, which then damage the gas-blood barrier [65]. During aging, lungs tend to have low-grade inflammation, such as an increased neutrophil response [49, 65].
Inflammatory changes associated with aging can lead to increased lung infection rates in older patients [59]. In contrast, neutrophils flow into the lungs and the associated inflammatory mediators are less reactive in newborn and juvenile subjects. The functions of lung dendritic cells, NK cells, macrophages, and neutrophils decline with age and reduce the body's defenses against external pathogenic microorganisms [59].

In summary, neutrophils accumulate in the lungs of elderly patients and cannot be easily discharged, which not only damages the innate immune response of the alveoli but also promotes inflammation. The number of alveoli cells declines in this condition, causing hyaline membrane formation, pulmonary edema, and other lung injuries. The respiratory disorders caused by COVID-19 lead to a sharp reduction in blood oxygen concentration and aggravate organ damage.

\section{Heart aging and COVID-19}

Worldwide, a large proportion of COVID-19 patients have cardiovascular disease. In China, one study reported that $15 \%$ and $2.5 \%$ of patients with COVID-19 presented with hypertension and cardiovascular disease, respectively [9]; in New York, the same complications accounted for $57 \%$ and $11 \%$ of patients, respectively [6]. In a region of Italy, $49 \%$ of patients had hypertension and $21 \%$ had coronary heart disease, and the elderly with hypertension had a higher mortality rate with respect to ICU deaths [10]. Elderly patients have a more acute presentation. Some COVID-19 patients have acute heart injury [8] or show inflammation-related cell infiltration in the myocardium [66]. Deceased patients with myocardial injury show elevated levels of troponin [67].

The impact of SARS-CoV-2 on ACE2 interferes with the regulation of the RAS in heart aging. As previously mentioned, SARS-CoV-2 infection can result in the downregulation of ACE2. In aging, high levels of ACE2 can effectively protect against Ang II-induced cardiac fibrosis and hypertrophy [68]. However, the hearts of older subjects have lower ACE2 levels and fibroblast activation and transition to a myofibroblast phenotype [69]. Some COVID-19 patients typically show increased IL-6 and C-reactive protein levels before death $[14,55]$, indicative of the progress of inflammation in the COVID-19 heart. The release of proinflammatory factors can cause heart damage [32], exacerbating myocardial cell apoptosis through various signaling pathways [69]. Cumulative heart injury due to hypertension, valvular heart disease, and heart failure in the elderly can lead to a low-grade inflammatory response. Low-grade inflammation maintains RAS activation and oxidative stress. As the anti-peroxidation effect of ACE2 can protect the heart blood vessels [70], 
the lack of ACE2 in the myocardium due to aging enhances oxidative damage and promotes inflammatory responses in the injured area. An imbalance between ACE and ACE2 exacerbates cellular damage among elderly patients when the myocardium undergoes an inflammatory reaction in COVID-19.

Atrial fibrosis occurs as a consequence of cardiovascular diseases during aging and can cause atrial overload and stretching [69]. The downregulation of ACE2 is associated with the occurrence of cardiac fibrosis. Fibrosis-induced changes to the heart structure and the associated increase in the number of fibroblasts can lead to more frequent arrhythmias and their progression to persistent or permanent arrhythmias. Several studies have mentioned the gradually increasing risk of arrhythmia in aging [71, 72]. In COVID-19 patients, the hyaline membrane can lead to a sharp drop in blood oxygen content [55] and puts extra strain on the heart. Cardiomyocyte energy metabolism can be damaged by the decrease in blood oxygen content. Right ventricular load is further increased because of edema and hyaline membrane formation in the aged lung, which increases pulmonary vascular resistance. If COVID-19 patients have an underlying heart condition and hypertension that have already damaged the cardiomyocytes, heart failure or arrhythmia can easily and rapidly occur in an already damaged lung.

Aging can decrease the tolerance to COVID-19 treatment in an aged heart. The use of chloroquine or hydroxychloroquine leads to an extension of the Q-T interval [73]. This finding indicates that the use of these drugs will also increase the risk of arrhythmia. Considering the decline that occurs in the pump function of the heart in the elderly, special attention should be paid to changes in the electrocardiography reads of these patients when selecting COVID-19 drug treatment. In patients with pneumonia, right heart failure and elevated levels of NT-ProBNP (a marker of heart failure) [74] are suggestive of a worsening of the condition and are associated with a significant increase in the fatality rate [75], which should also be considered when administering COVID-19 treatment.

\section{Kidney aging and COVID-19}

Patients with severe COVID-19 are more likely to have kidney injury. One study showed that approximately $15 \%$ of COVID-19 patients had acute kidney injury (AKI) [14]. Aging, comorbidities, and medical intervention predispose elderly patients to AKI [76]. In SARS-CoV infections, viral particles were found in the kidney, suggesting that the virus can infect this organ [77]. Given that SARS-CoV-2 has a higher affinity for humans than SARS-CoV [17], the kidneys are more likely to be a target of infection for SARS-CoV-2, resulting in AKI in elderly patients.

Elderly patients are considerably more likely to have an AKI in COVID-19 because the renal tubular function can be damaged by free radicals produced in the aging body [78]. The kidney tissue structure displays a reduced number of healthy nephrons, changes to the tubulointerstitium, thickening of the glomerular basement membrane, and increased glomerulosclerosis. Increased Ang II activity in the elderly leads to the accumulation of proinflammatory cells, thereby exacerbating the injury to renal tubular endothelial cells. In aging, the kidney lacks ACE2 and Ang-(1-7), resulting in glomerular sclerosis, which limits the role of proximal tubular cells and podocytes in resisting oxidative stress and cell proliferation [32, 78]. A cytokine storm caused by COVID-19 increases circulating IL-6 levels in the body; hence, the proinflammatory effects, combined with a lack of renal ACE2 protection, leads to a severe functional injury to the kidneys.

CKD (affected 5\% of the 5,700 COVID-19 patients in the New York study [6]), hypertension, and heart failure are all comorbidities that increase the risk of AKI and are commonly coexisting illnesses in COVID-19 patients [9]. Patients with CKD usually have increased levels of AT1R in peripheral leukocytes [79], indicating that continuous Ang II activation can exacerbate kidney injury [80]. Uremic conditions due to CKD promote the excessive activation of monocyte ACE levels and inhibition of ACE2, thereby promoting endothelial adhesion and migration and possibly also atherosclerosis development [79]. The changes in blood flow in renal atherosclerosis reduce kidney elasticity and thicken the tunica intima, leading to prerenal AKI [76]. Renin secreted by glomerular cells is a key hormone for the production of Ang II, and glomerular cells are regulated by the RAS. As previously mentioned, coronavirus infection can reduce the concentrations of ACE2 on the cell surface, including in renal cells, which can lead to abnormal metabolism in the kidneys, and even in the whole body.

Because the excretory function of the kidney is lowered in aging, its capacity to excrete drugs and harmful metabolites is reduced. Electrolyte disturbances, such as hypokalemia, often occur as a result of fever, gastrointestinal symptoms, and reduced ACE2 levels in COVID-19 [81]. The aging kidney can undergo morphological and anatomical changes and display reduced filtration capacity [78], leading to increased drug-associated toxicity in the body. The disease process promotes an unstable internal environment and is more likely to result in a serious acid-base imbalance 
in the elderly, and even result in severe conditions. In terms of treatment, clinicians should be cautious when administering drugs that are excreted through the kidneys, especially in patients with a preexisting kidney injury.

\section{Aging and vascular injury in COVID-19}

Patients with COVID-19 have a high incidence of vasculitis and thrombosis in the lungs [82]. Some can also have Kawasaki disease [83], petechiae, tiny bruises, and/or transient livedoid eruptions in the skin [84]. Biochemical indicators such as prothrombin time, activated partial thromboplastin time, fibrinogen, and D-dimer are significantly increased or decreased [55], indicating that SARS-CoV-2 also affects the blood system and induces disseminated intravascular coagulation (DIC).

Vascular disease, a significant problem in the elderly, can easily cause serious endothelial damage during COVID-19 evolution. Aging arteries are characterized by changes in microRNA expression patterns, autophagy, smooth muscle cell migration and proliferation, and dynamic calcification [68], while vasculopathy is associated with increased ROS production, oxidative stress and deficiency of peroxidase [85]. Increased blood pressure, elevated blood sugar, obesity, low-density lipoprotein cholesterol, and sodium intake in the elderly can all influence endothelial function through oxidative stress and inflammatory disorders. The arterial walls develop atherosclerotic plaques and have increased rigidity and stiffness, leading to a reduction in arterial compliance [68]. Pathological changes during blood vessel aging play a role in the initial stages of DIC. Endothelial cells function to promote vasodilation, fibrinolysis, and suppress aggregation, and can inhibit the formation of thrombosis [28]. Endothelial cell dysfunction can facilitate the occurrence of microthrombosis [68, 86, 87]. Because ACE2 can increase the activity of endothelial cells, in the absence of ACE2 in COVID-19 and aging, Ang II activation causes smooth muscle contraction, induce high expression of proinflammatory factors, promote vascular contraction and endothelial dysfunction, all of which contribute to increased vascular permeability and eventually become predisposing factors for DIC [28]. A proinflammatory status in aging leads to enhanced plasma concentrations of inflammatory proteins [68]. When suffering from a COVID-19associated cytokine storm, the anti-inflammatory properties of aging arteries decrease; this, when coupled with the presence of SARS-CoV-2 virus within the endothelial cells [82], is more likely to cause widespread coagulation throughout the body.
CD147, is expressed on the surface of blood cells [36]. Increased CD147 expression can occur during platelet activation or some inflammation-related responses [37], suggesting that the expression of CD147 may increase after SARS-CoV-2 infection. The combination of these factors can render the elderly more prone to systemic edema and congestion when suffering from COVID-19related pneumonia, and is more likely to cause functional changes in organs with rich blood flow such as the kidneys, lungs, heart, and brain.

\section{Aging of the nervous system and COVID-19}

Many patients with COVID-19 have clear neurological symptoms such as cerebrovascular disease, unconsciousness, and skeletal muscle tremors [88], and at least one study reported the presence of SARS-CoV-2 mRNA in the cerebrospinal fluid of patients [89].

Elderly patients are more likely to be infected by SARS-CoV-2 in the central nervous system. Two other coronaviruses-SARS-CoV and MARS-CoV-display neuronal tropism $[90,91]$, which suggests that SARSCoV-2 may have the same feature. Increased Ang II levels resulting from inflammatory responses such as the cytokine storm will lead to an increase in the permeability of blood vessels in the brain, increasing the possibility that the virus may reach the brain. Oxidative stress resulting from aging and inflammation also upregulates Ang II expression in the brain [92]. Thus, increased Ang II levels during aging can enlarge the site and scope of the infection among the elderly. When SARS-CoV-2 invades the brain stem, respiratory failure and organ disorders can become much more common symptoms of COVID-19.

Nerve aging and chronic disease are associated with the production of the proinflammatory factors IL-6 and IL$1 \beta$ by microglia. The most common manifestations of deteriorating COVID-19 pneumonia in elderly patients are severe ARDS and MODS, both of which display increased circulating IL-6 levels. The dependence of the brain on a high oxygen concentration, unsaturated fatty acids, and strong mitochondrial metabolism lead to obvious high oxidative stress- and mitochondrial-related damage as a result of aging and microglial priming [93]. Brain damage in hypoxia due to COVID-19 leads to excessive activation of microglia and release of proinflammatory factors [93], which further aggravates the brain injury. SARS-CoV invasion of the brain was reported to increase the density of microglia [91]. This suggests that SARS-CoV-2 infection can also promote the overactivation of microglia, leading to a more severe inflammatory response, and even an "intracerebral storm" of inflammatory factors. SARSCoV-2 infection may further reduce the availability of 
ERS-associated proteins, as well as that of GRP78 and other chaperone proteins, in the elderly brain. This will cause apoptosis [58] and exacerbate brain damage.

Patients with COVID-19 often have increased bronchial secretions [42], and aspiration pneumonia may also be a possible cause for disease aggravation. Blockages caused by the secretions can lead to severe hypoxemia and lung tissue injury. In COVID-19 patients, hypoxia and the impact of SARS-CoV-2 on neurons reduce nerve responses, whereby the bronchial secreta cannot be effectively discharged through coughing and swallowing reflexes. Several neurodegenerative diseases can lead to slower reflexes in elderly patients when compared with young patients, which means that the nerve responses in the elderly can be more easily reduced. A recent study [94] reported that the use of an ACE inhibitor can alleviate pneumonia in stroke patients by reducing the effects of Ang II on the brain as well as substance $\mathrm{P}$ and bradykinin metabolism. These effects can enhance the cough reflex, prevent aspiration, and ultimately reduce the risk of pneumonia in the elderly; however, further evidence is required with respect to the risks and benefits of ACE inhibitor application.

\section{Diabetes in the elderly and susceptibility to COVID-19}

In the elderly, aging is associated with diabetes, which can lead to chronic diseases such as hypertension, atherosclerosis, and kidney injury [95]. Zhou et al. reported a $19 \%$ incidence rate of diabetes among COVID-19 patients [14], similar to that reported in other studies $[6,9,10]$. This suggests that diabetes is an underlying risk of developing severe COVID-19.

Diabetes is one of the most commonly diagnosed agerelated comorbidities, and promotes inflammation and SARS-CoV-2 infection in the aging body. Hyperglycemia decreases proximal tubule ACE2 by activating the process of ACE2 shedding through ADAM17-mediated cleavage described in the previous [30]. The virus can attach to the shedding ACE2 and spread throughout the body. Hyperglycemia-induced ACE2 glycosylation can also lead to a decline in ACE2 function. Meanwhile, in type 2 diabetes, insulin can activate vascular ACE activity in vascular smooth muscle cells, and inhibit angiotensinogen and renin expression. In aging, the diabetes can enhance the sensitivity of local cells to inflammatory mediators and activate toll-like receptors to cause insulin resistance [95]. Hyperglycemia can enhance Ang II concentrations in cardiomyocytes and fibroblasts, which promotes the release of inflammatory mediators. Hyperglycemia also induces increased expression of CD147 [36], leading to an increased probability of SARS-CoV-2 infection. Because of the close link between matrix metalloproteinases (MMPs) and CD147 [37], hyperglycemia can influence the migration of monocytes and the function of fibroblasts, as well as the release of TNF- $\alpha$, vascular endothelial growth factor (VEGF), and IL-1 $\beta$. Elevated expression of MMPs can also promote pulmonary inflammation, causing a cytokine storm, which is difficult to suppress, and result in systemic injury.

Concomitantly, diabetes and islet aging can affect the whole body in patients with deteriorating COVID-19. Strong ACE2 protein immunostaining was observed in the islet cells of patients with SARS-CoV infection: the higher the level of immunostaining, the greater the damage to the organs [96]. This suggests that the pancreas can also be attacked and damaged by SARSCoV-2. This damage to pancreatic islet cells leads to abnormal insulin secretion, exacerbates the endocrine disorder in patients, and aggravates the damage to other organs [97]. COVID-19 may further lead to organ and tissue dysfunction because of the increased risk of cardiovascular disease and stroke resulting from diabetic nephropathy and diabetes [98]. High levels of insulin exert growth stimulatory effects on vascular cells and increase the formation of atherosclerotic plaques [99]. In a review of the relationship between GRP78 and aging [58], insulin secretion and insulin-like growth factor (IGF-1)-mediated regulation of GRP78 appeared to enhance the adaptive capacity of the UPR under ERS conditions. Aging can cause impaired autophagy in islet cells, which can lead to impaired $\beta$ cell function. The accumulation of misfolded and aggregated proteins can activate the UPR [100]. GRP78 also plays a role in glucose homeostasis and has antiobesity properties. If the activity of GRP78 changes under the influence of COVID-19, the steady-state of insulin and ERS will change, resulting in an ERSinduced decline in immune resistance.

\section{SUMMARY}

The SARS-CoV-2 virus outbreak is ongoing since December 2019. Numerous studies have attempted to clarify the relevant characteristics of the virus. However, the exact mechanisms underlying the high mortality rate of patients with chronic diseases and older patients requires further in-depth analysis. To date, the vaccine for the SARS-Cov-2 is still in development, and there is no specific drugs targeting the virus. Therefore, in clinical practice, it is necessary to pay close attention to changes in the condition of elderly patients, make accurate judgments, and prevent cytokine storms and multiple organ failure in as timely a manner as possible. Timely prevention and correct 
treatment at the time of disease onset can prevent disease progression and the deterioration of patients, thereby reducing mortality.

\section{AUTHOR CONTRIBUTIONS}

P.D. Zhang, Y. Guo and Z.J. Wu conceived and designed the study. L.M. Pang, Y. Liu and M.Z. Shen performed the literature search and drafted the manuscript. J.J. Ye screened and fitted the data. All authors critically revised the manuscript and approved the final version.

\section{CONFLICTS OF INTEREST}

The authors declare no conflicts of interest.

\section{FUNDING}

This work was supported by the Guangdong Medical Science and Technology Research Foundation (A2020162, C2019119).

\section{REFERENCES}

1. López-Otín C, Blasco MA, Partridge L, Serrano $M$, Kroemer G. The hallmarks of aging. Cell. 2013; 153:1194-217.

https://doi.org/10.1016/i.cell.2013.05.039 PMID:23746838

2. Ferrucci L, Levine ME, Kuo PL, Simonsick EM. Time and the metrics of aging. Circ Res. 2018; 123:740-44. https://doi.org/10.1161/CIRCRESAHA.118.312816 PMID: 30355074

3. Partridge L, Deelen J, Slagboom PE. Facing up to the global challenges of ageing. Nature. 2018; 561:45-56. https://doi.org/10.1038/s41586-018-0457-8 PMID:30185958

4. Ashapkin VV, Kutueva LI, Kurchashova SY, Kireev II. Are there common mechanisms between the HutchinsonGilford progeria syndrome and natural aging? Front Genet. 2019; 10:455.

https://doi.org/10.3389/fgene.2019.00455

PMID:31156709

5. Young BE, Ong SW, Kalimuddin S, Low JG, Tan SY, Loh J, Ng OT, Marimuthu K, Ang LW, Mak TM, Lau SK, Anderson DE, Chan KS, et al, and Singapore 2019 Novel Coronavirus Outbreak Research Team. Epidemiologic features and clinical course of patients infected with SARS-CoV-2 in Singapore. JAMA. 2020; 323:1488-94. https://doi.org/10.1001/jama.2020.3204 PMID: $\underline{32125362}$

6. Richardson S, Hirsch JS, Narasimhan M, Crawford JM, McGinn T, Davidson KW, Barnaby DP, Becker LB, Chelico JD, Cohen SL, Cookingham J, Coppa K,
Diefenbach MA, et al, and the Northwell COVID-19 Research Consortium. Presenting characteristics, comorbidities, and outcomes among 5700 patients hospitalized with COVID-19 in the New York city area. JAMA. 2020; 323:2052-59.

https://doi.org/10.1001/jama.2020.6775

PMID:32320003

7. Lee JY, Kim HA, Huh K, Hyun M, Rhee JY, Jang S, Kim JY, Peck KR, Chang HH. Risk factors for mortality and respiratory support in elderly patients hospitalized with COVID-19 in Korea. J Korean Med Sci. 2020; 35:e223.

https://doi.org/10.3346/jkms.2020.35.e223 PMID:32537957

8. Huang $C$, Wang $Y$, Li X, Ren L, Zhao J, Hu Y, Zhang L, Fan G, Xu J, Gu X, Cheng Z, Yu T, Xia J, et al. Clinical features of patients infected with 2019 novel coronavirus in Wuhan, China. Lancet. 2020; 395:497-506.

https://doi.org/10.1016/S0140-6736(20)30183-5 PMID:31986264

9. Guan WJ, Ni ZY, Hu Y, Liang WH, Ou CQ, He JX, Liu L, Shan H, Lei CL, Hui DS, Du B, Li LJ, Zeng G, et al, and China Medical Treatment Expert Group for Covid-19. Clinical characteristics of coronavirus disease 2019 in China. N Engl J Med. 2020; 382:1708-20.

https://doi.org/10.1056/NEJMoa2002032 PMID:32109013

10. Grasselli G, Zangrillo A, Zanella A, Antonelli M, Cabrini L, Castelli A, Cereda D, Coluccello A, Foti G, Fumagalli R, lotti G, Latronico N, Lorini L, et al, and COVID-19 Lombardy ICU Network. Baseline characteristics and outcomes of 1591 patients infected with SARS-CoV-2 admitted to ICUs of the Lombardy region, Italy. JAMA. 2020; 323:1574-81.

https://doi.org/10.1001/jama.2020.5394 PMID:32250385

11. Gold JA, Wong KK, Szablewski CM, Patel PR, Rossow J, da Silva J, Natarajan P, Morris SB, Fanfair RN, RogersBrown J, Bruce BB, Browning SD, Hernandez-Romieu $A C$, et al. Characteristics and clinical outcomes of adult patients hospitalized with COVID-19 - Georgia, March 2020. MMWR Morb Mortal Wkly Rep. 2020; 69:545-50.

https://doi.org/10.15585/mmwr.mm6918e1 PMID:32379729

12. Alsofayan YM, Althunayyan SM, Khan AA, Hakawi AM, Assiri AM. Clinical characteristics of COVID-19 in Saudi Arabia: a national retrospective study. J Infect Public Health. 2020; 13:920-25. https://doi.org/10.1016/i.jiph.2020.05.026 PMID: $\underline{32534945}$

13. Blagosklonny MV. From causes of aging to death from COVID-19. Aging (Albany NY). 2020; 12:10004-21. 
https://doi.org/10.18632/aging.103493

PMID:32534452

14. Zhou F, Yu T, Du R, Fan G, Liu Y, Liu Z, Xiang J, Wang Y, Song B, Gu X, Guan L, Wei Y, Li H, et al. Clinical course and risk factors for mortality of adult inpatients with COVID-19 in Wuhan, China: a retrospective cohort study. Lancet. 2020; 395:1054-62.

https://doi.org/10.1016/S0140-6736(20)30566-3 PMID:32171076

15. Wu Z, McGoogan JM. Characteristics of and important lessons from the coronavirus disease 2019 (COVID-19) outbreak in China: summary of a report of 72314 cases from the Chinese center for disease control and prevention. JAMA. 2020; 323:1239-42.

https://doi.org/10.1001/jama.2020.2648

PMID:32091533

16. Xu X, Chen P, Wang J, Feng J, Zhou H, Li X, Zhong W, Hao P. Evolution of the novel coronavirus from the ongoing Wuhan outbreak and modeling of its spike protein for risk of human transmission. Sci China Life Sci. 2020; 63:457-60.

https://doi.org/10.1007/s11427-020-1637-5

PMID:32009228

17. Hoffmann $M$, Kleine-Weber $H$, Schroeder $S$, Krüger $N$, Herrler T, Erichsen S, Schiergens TS, Herrler G, Wu NH, Nitsche A, Müller MA, Drosten C, Pöhlmann S. SARSCoV-2 cell entry depends on ACE2 and TMPRSS2 and is blocked by a clinically proven protease inhibitor. Cell. 2020; 181:271-80.e8.

https://doi.org/10.1016/j.cell.2020.02.052

PMID:32142651

18. Eder P, Łodyga M, Dobrowolska A, Rydzewska G, Kamhieh-Milz J. Addressing multiple gastroenterological aspects of coronavirus disease 2019. Pol Arch Intern Med. 2020; 130:420-30.

https://doi.org/10.20452/pamw.15332

PMID:32356641

19. Zhou $P$, Yang $X L$, Wang $X G$, Hu B, Zhang $L$, Zhang $W$, Si HR, Zhu Y, Li B, Huang CL, Chen HD, Chen J, Luo Y, et al. A pneumonia outbreak associated with a new coronavirus of probable bat origin. Nature. 2020; 579:270-73.

https://doi.org/10.1038/s41586-020-2012-7

PMID:32015507

20. Wrapp D, Wang N, Corbett KS, Goldsmith JA, Hsieh CL, Abiona O, Graham BS, McLellan JS. cryo-EM structure of the 2019-nCoV spike in the prefusion conformation. Science. 2020; 367:1260-63.

https://doi.org/10.1126/science.abb2507

PMID:32075877

21. Li W, Moore MJ, Vasilieva N, Sui J, Wong SK, Berne MA, Somasundaran M, Sullivan JL, Luzuriaga K, Greenough
TC, Choe H, Farzan M. Angiotensin-converting enzyme 2 is a functional receptor for the SARS coronavirus. Nature. 2003; 426:450-54.

https://doi.org/10.1038/nature02145 PMID:14647384

22. Kuba K, Imai Y, Rao S, Gao H, Guo F, Guan B, Huan Y, Yang P, Zhang Y, Deng W, Bao L, Zhang B, Liu G, et al. A crucial role of angiotensin converting enzyme 2 (ACE2) in SARS coronavirus-induced lung injury. Nat Med. 2005; 11:875-79.

https://doi.org/10.1038/nm1267

PMID:16007097

23. Saheb Sharif-Askari N, Saheb Sharif-Askari F, Alabed M, Temsah MH, Al Heialy S, Hamid Q, Halwani R. Airways expression of SARS-CoV-2 receptor, ACE2, and TMPRSS2 is lower in children than adults and increases with smoking and COPD. Mol Ther Methods Clin Dev. 2020; 18:1-6.

https://doi.org/10.1016/i.omtm.2020.05.013 PMID:32537478

24. Sampson AK, Moritz KM, Denton KM. Postnatal ontogeny of angiotensin receptors and ACE2 in male and female rats. Gend Med. 2012; 9:21-32. https://doi.org/10.1016/i.genm.2011.12.003 PMID:22266307

25. Li MY, Li L, Zhang Y, Wang XS. Expression of the SARSCoV-2 cell receptor gene ACE2 in a wide variety of human tissues. Infect Dis Poverty. 2020; 9:45. https://doi.org/10.1186/s40249-020-00662-x PMID:32345362

26. Gallagher PE, Ferrario CM, Tallant EA. Regulation of ACE2 in cardiac myocytes and fibroblasts. Am J Physiol Heart Circ Physiol. 2008; 295:H2373-79. https://doi.org/10.1152/ajpheart.00426.2008 PMID:18849338

27. Oudit GY, Kassiri Z, Patel MP, Chappell M, Butany J, Backx PH, Tsushima RG, Scholey JW, Khokha R, Penninger JM. Angiotensin II-mediated oxidative stress and inflammation mediate the age-dependent cardiomyopathy in ACE2 null mice. Cardiovasc Res. 2007; 75:29-39.

https://doi.org/10.1016/j.cardiores.2007.04.007 PMID: 17499227

28. Zhang $\mathrm{YH}$, Zhang $\mathrm{YH}$, Dong $\mathrm{XF}$, Hao QQ, Zhou XM, Yu QT, Li SY, Chen X, Tengbeh AF, Dong B, Zhang Y. ACE2 and ang-(1-7) protect endothelial cell function and prevent early atherosclerosis by inhibiting inflammatory response. Inflamm Res. 2015; 64:253-60.

https://doi.org/10.1007/s00011-015-0805-1 PMID:25721616

29. Fernández-Atucha $A$, Izagirre $A$, Fraile-Bermúdez $A B$, Kortajarena M, Larrinaga G, Martinez-Lage $P$, Echevarría E, Gil J. Sex differences in the aging pattern 
of renin-angiotensin system serum peptidases. Biol Sex Differ. 2017; 8:5.

https://doi.org/10.1186/s13293-017-0128-8

PMID:28174624

30. Anguiano L, Riera M, Pascual J, Soler MJ. Circulating ACE2 in cardiovascular and kidney diseases. Curr Med Chem. 2017; 24:3231-41. https://doi.org/10.2174/0929867324666170414162841 PMID:28413960

31. Forrester SJ, Booz GW, Sigmund CD, Coffman TM, Kawai T, Rizzo V, Scalia R, Eguchi S. Angiotensin II signal transduction: an update on mechanisms of physiology and pathophysiology. Physiol Rev. 2018; 98:1627-738. https://doi.org/10.1152/physrev.00038.2017 PMID:29873596

32. Simões E Silva AC, Teixeira MM. ACE inhibition, ACE2 and angiotensin-(1-7) axis in kidney and cardiac inflammation and fibrosis. Pharmacol Res. 2016; 107:154-62.

https://doi.org/10.1016/i.phrs.2016.03.018 PMID:26995300

33. Ibrahim IM, Abdelmalek DH, Elshahat ME, Elfiky AA. COVID-19 spike-host cell receptor GRP78 binding site prediction. J Infect. 2020; 80:554-62.

https://doi.org/10.1016/j.jinf.2020.02.026 PMID:32169481

34. Wang K, Chen W, Zhou YS, Lian JQ, Zhang Z, Du P, Gong L, Zhang Y, Cui HY, Geng JJ, Wang B, Sun XX, Wang CF, et al. SARS-CoV-2 invades host cells via a novel route: CD147-spike protein. bioRxiv. 2020. [Epub ahead of print].

https://doi.org/10.1101/2020.03.14.988345

35. Liu C, von Brunn A, Zhu D. Cyclophilin a and CD147: novel therapeutic targets for the treatment of COVID19. Med Drug Discov. 2020; 7:100056.

https://doi.org/10.1016/i.medidd.2020.100056 PMID:32835213

36. Ulrich H, Pillat MM. CD147 as a target for COVID-19 treatment: suggested effects of azithromycin and stem cell engagement. Stem Cell Rev Rep. 2020; 16:434-40.

https://doi.org/10.1007/s12015-020-09976-7

PMID:32307653

37. von Ungern-Sternberg SNI, Zernecke A, Seizer P. Extracellular Matrix Metalloproteinase Inducer EMMPRIN (CD147) in Cardiovascular Disease. Int J Mol Sci. 2018; 19:507.

https://doi.org/10.3390/ijms19020507 PMID:29419744

38. Li J, Xie H, Yi M, Peng L, Lei D, Chen X, Jian D. Expression of cyclophilin a and CD147 during skin aging. Zhong Nan Da Xue Xue Bao Yi Xue Ban. 2011; $36: 203-11$. https://doi.org/10.3969/j.issn.1672-7347.2011.03.003 PMID:21464540

39. Gong J, Wang XZ, Wang T, Chen JJ, Xie XY, Hu H, Yu F, Liu HL, Jiang XY, Fan HD. Molecular signal networks and regulating mechanisms of the unfolded protein response. J Zhejiang Univ Sci B. 2017; 18:1-14. https://doi.org/10.1631/jzus.B1600043 PMID:28070992

40. Köseler A, Sabirli R, Gören T, Türkçüer I, Kurt Ö. Endoplasmic reticulum stress markers in SARS-COV-2 infection and pneumonia: case-control study. In Vivo. 2020; 34:1645-50. https://doi.org/10.21873/invivo.11956 PMID:32503824

41. Park KW, Eun Kim G, Morales R, Moda F, MorenoGonzalez I, Concha-Marambio L, Lee AS, Hetz C, Soto C. The endoplasmic reticulum chaperone GRP78/BiP modulates prion propagation in vitro and in vivo. Sci Rep. 2017; 7:44723. https://doi.org/10.1038/srep44723 PMID:28333162

42. Xu Z, Shi L, Wang $Y$, Zhang J, Huang L, Zhang $C$, Liu $S$, Zhao P, Liu H, Zhu L, Tai Y, Bai C, Gao T, et al. Pathological findings of COVID-19 associated with acute respiratory distress syndrome. Lancet Respir Med. 2020; 8:420-22.

https://doi.org/10.1016/S2213-2600(20)30076-X PMID:32085846

43. Liberale L, Montecucco F, Tardif JC, Libby P, Camici GG. Inflamm-ageing: the role of inflammation in agedependent cardiovascular disease. Eur Heart J. 2020; 41:2974-82.

https://doi.org/10.1093/eurheartj/ehz961 PMID:32006431

44. Mueller AL, McNamara MS, Sinclair DA. Why does COVID-19 disproportionately affect older people? Aging (Albany NY). 2020; 12:9959-81.

https://doi.org/10.18632/aging.103344 PMID: $\underline{32470948}$

45. Simon AK, Hollander GA, McMichael A. Evolution of the immune system in humans from infancy to old age. Proc Biol Sci. 2015; 282:20143085.

https://doi.org/10.1098/rspb.2014.3085 PMID:26702035

46. Bone RC. Immunologic dissonance: a continuing evolution in our understanding of the systemic inflammatory response syndrome (SIRS) and the multiple organ dysfunction syndrome (MODS). Ann Intern Med. 1996; 125:680-87.

https://doi.org/10.7326/0003-4819-125-8-199610150$\underline{00009}$ PMID:

47. Man MQ, Elias PM. Could inflammaging and its sequelae be prevented or mitigated? Clin Interv Aging. 2019; 14:2301-04. 
https://doi.org/10.2147/CIA.S235595

PMID:31920294

48. Santos RA, Sampaio WO, Alzamora AC, Motta-Santos D, Alenina N, Bader M, Campagnole-Santos MJ. The ACE2/Angiotensin-(1-7)/MAS axis of the reninangiotensin system: focus on angiotensin-(1-7). Physiol Rev. 2018; 98:505-53.

https://doi.org/10.1152/physrev.00023.2016 PMID:29351514

49. Schouten LR, van Kaam AH, Kohse F, Veltkamp F, Bos LD, de Beer FM, van Hooijdonk RT, Horn J, Straat M, Witteveen E, Glas GJ, Wieske L, van Vught LA, et al, and MARS consortium. Age-dependent differences in pulmonary host responses in ARDS: a prospective observational cohort study. Ann Intensive Care. 2019; 9:55.

https://doi.org/10.1186/s13613-019-0529-4 PMID:31089908

50. Bar-Natan M, Hymes KB. Management of intraoperative coagulopathy. Neurosurg Clin N Am. 2018; 29:557-65. https://doi.org/10.1016/i.nec.2018.06.007 PMID:30223968

51. Harenberg J, Favaloro E. COVID-19: progression of disease and intravascular coagulation - present status and future perspectives. Clin Chem Lab Med. 2020; 58:1029-36.

https://doi.org/10.1515/cclm-2020-0502 PMID:32406381

52. Cevenini E, Monti D, Franceschi C. Inflamm-ageing. Curr Opin Clin Nutr Metab Care. 2013; 16:14-20. https://doi.org/10.1097/MCO.0b013e32835ada13 PMID:23132168

53. Calder PC, Bosco N, Bourdet-Sicard R, Capuron L, Delzenne N, Doré J, Franceschi C, Lehtinen MJ, Recker T, Salvioli S, Visioli F. Health relevance of the modification of low grade inflammation in ageing (inflammageing) and the role of nutrition. Ageing Res Rev. 2017; 40:95-119.

https://doi.org/10.1016/i.arr.2017.09.001 PMID:28899766

54. Vlahos R, Stambas J, Bozinovski S, Broughton BR, Drummond GR, Selemidis $S$. Inhibition of Nox2 oxidase activity ameliorates influenza a virusinduced lung inflammation. PLoS Pathog. 2011; 7:e1001271.

https://doi.org/10.1371/journal.ppat.1001271 PMID:21304882

55. Wu C, Chen X, Cai Y, Xia J, Zhou X, Xu S, Huang H, Zhang L, Zhou X, Du C, Zhang Y, Song J, Wang S, et al. Risk factors associated with acute respiratory distress syndrome and death in patients with coronavirus disease 2019 pneumonia in Wuhan, China. JAMA Intern Med. 2020; 180:934-43.

https://doi.org/10.1001/jamainternmed.2020.0994 PMID:32167524

56. Heurich A, Hofmann-Winkler H, Gierer S, Liepold $T$, Jahn O, Pöhlmann S. TMPRSS2 and ADAM17 cleave ACE2 differentially and only proteolysis by TMPRSS2 augments entry driven by the severe acute respiratory syndrome coronavirus spike protein. J Virol. 2014; 88:1293-307.

https://doi.org/10.1128/JVI.02202-13 PMID:24227843

57. Borok Z, Horie M, Flodby P, Wang H, Liu Y, Ganesh S, Firth AL, Minoo P, Li C, Beers MF, Lee AS, Zhou B. Grp78 loss in epithelial progenitors reveals an agelinked role for endoplasmic reticulum stress in pulmonary fibrosis. Am J Respir Crit Care Med. 2020; 201:198-211.

https://doi.org/10.1164/rccm.201902-04510C PMID:31738079

58. Pfaffenbach KT, Lee AS. The critical role of GRP78 in physiologic and pathologic stress. Curr Opin Cell Biol. 2011; 23:150-56. https://doi.org/10.1016/i.ceb.2010.09.007 PMID:20970977

59. Boe DM, Boule LA, Kovacs EJ. Innate immune responses in the ageing lung. Clin Exp Immunol. 2017; 187:16-25. https://doi.org/10.1111/cei.12881 PMID:27711979

60. Brandsma CA, de Vries $M$, Costa $R$, Woldhuis RR, Königshoff $M$, Timens $W$. Lung ageing and COPD: is there a role for ageing in abnormal tissue repair? Eur Respir Rev. 2017; 26:170073. https://doi.org/10.1183/16000617.0073-2017 PMID:29212834

61. MacNee W. Accelerated lung aging: a novel pathogenic mechanism of chronic obstructive pulmonary disease (COPD). Biochem Soc Trans. 2009; 37:819-23.

https://doi.org/10.1042/BST0370819 PMID:19614601

62. Kelley RC, Ferreira LF. Diaphragm abnormalities in heart failure and aging: mechanisms and integration of cardiovascular and respiratory pathophysiology. Heart Fail Rev. 2017; 22:191-207. https://doi.org/10.1007/s10741-016-9549-4 PMID:27000754

63. Ogier M, Andéol G, Sagui E, Dal Bo G. How to detect and track chronic neurologic sequelae of COVID-19? Use of auditory brainstem responses and neuroimaging for long-term patient follow-up. Brain Behav Immun Health. 2020; 5:100081.

https://doi.org/10.1016/i.bbih.2020.100081 PMID: $\underline{32427134}$ 
64. Li M, Lei P, Zeng B, Li Z, Yu P, Fan B, Wang C, Li Z, Zhou J, $\mathrm{Hu} \mathrm{S}$, Liu H. Coronavirus disease (COVID-19): spectrum of CT findings and temporal progression of the disease. Acad Radiol. 2020; 27:603-08.

https://doi.org/10.1016/i.acra.2020.03.003

PMID:32204987

65. Kling KM, Lopez-Rodriguez E, Pfarrer C, Mühlfeld C, Brandenberger $\mathrm{C}$. Aging exacerbates acute lung injuryinduced changes of the air-blood barrier, lung function, and inflammation in the mouse. Am J Physiol Lung Cell Mol Physiol. 2017; 312:L1-12.

https://doi.org/10.1152/ajplung.00347.2016 PMID:27815259

66. Wang HJ, Du SH, Yue X, Chen CX. Review and prospect of pathological features of corona virus disease. Fa Yi Xue Za Zhi. 2020; 36:16-20.

https://doi.org/10.12116/j.issn.1004$\underline{\text { 5619.2020.01.004 PMID:32198986 }}$

67. Bavishi C, Bonow RO, Trivedi V, Abbott JD, Messerli FH, Bhatt DL. Acute myocardial injury in patients hospitalized with COVID-19 infection: a review. Prog Cardiovasc Dis. 2020; 63:682-89.

https://doi.org/10.1016/i.pcad.2020.05.013

PMID:32512122

68. Tesauro M, Mauriello A, Rovella V, AnnicchiaricoPetruzzelli M, Cardillo C, Melino G, Di Daniele N. Arterial ageing: from endothelial dysfunction to vascular calcification. J Intern Med. 2017; 281:471-82. https://doi.org/10.1111/joim.12605 PMID:28345303

69. Dzeshka MS, Lip GY, Snezhitskiy V, Shantsila E. Cardiac fibrosis in patients with atrial fibrillation: mechanisms and clinical implications. J Am Coll Cardiol. 2015; 66:943-59.

https://doi.org/10.1016/j.jacc.2015.06.1313

PMID:26293766

70. Donoghue M, Hsieh F, Baronas E, Godbout K, Gosselin M, Stagliano N, Donovan M, Woolf B, Robison K, Jeyaseelan R, Breitbart RE, Acton S. A novel angiotensin-converting enzyme-related carboxypeptidase (ACE2) converts angiotensin I to angiotensin 1-9. Circ Res. 2000; 87:E1-9.

https://doi.org/10.1161/01.res.87.5.e1

PMID:10969042

71. Jeevaratnam K, Chadda KR, Salvage SC, Valli $H$, Ahmad $S$, Grace AA, Huang CL. Ion channels, long QT syndrome and arrhythmogenesis in ageing. Clin Exp Pharmacol Physiol. 2017 (Suppl 1); 44:38-45.

https://doi.org/10.1111/1440-1681.12721

PMID:28024120

72. Macfarlane PW. The influence of age and sex on the electrocardiogram. Adv Exp Med Biol. 2018; 1065:93-106. https://doi.org/10.1007/978-3-319-77932-4 6 PMID: $\underline{30051379}$

73. Jankelson L, Karam G, Becker ML, Chinitz LA, Tsai MC. QT prolongation, torsades de pointes, and sudden death with short courses of chloroquine or hydroxychloroquine as used in COVID-19: a systematic review. Heart Rhythm. 2020; 17:1472-79.

https://doi.org/10.1016/i.hrthm.2020.05.008 PMID:32438018

74. Pemberton $\mathrm{CJ}$, Johnson $\mathrm{ML}$, Yandle TG, Espiner EA. Deconvolution analysis of cardiac natriuretic peptides during acute volume overload. Hypertension. 2000; 36:355-59.

https://doi.org/10.1161/01.hyp.36.3.355 PMID:10988264

75. Kolditz M, Braeken D, Ewig S, Rohde G. Severity assessment and the immediate and long-term prognosis in community-acquired pneumonia. Semin Respir Crit Care Med. 2016; 37:886-96. https://doi.org/10.1055/s-0036-1592127 PMID:27960212

76. Yokota LG, Sampaio BM, Rocha EP, Balbi AL, Sousa Prado IR, Ponce D. Acute kidney injury in elderly patients: narrative review on incidence, risk factors, and mortality. Int J Nephrol Renovasc Dis. 2018; 11:217-24. https://doi.org/10.2147/IJNRD.S170203 PMID:30147352

77. Gu J, Gong E, Zhang B, Zheng J, Gao Z, Zhong Y, Zou W, Zhan J, Wang S, Xie Z, Zhuang H, Wu B, Zhong H, et al. Multiple organ infection and the pathogenesis of SARS. J Exp Med. 2005; 202:415-24. https://doi.org/10.1084/jem.20050828 PMID:16043521

78. Li Z, Wang Z. Aging kidney and aging-related disease. Adv Exp Med Biol. 2018; 1086:169-87. https://doi.org/10.1007/978-981-13-1117-8 11 PMID:30232759

79. Trojanowicz B, Ulrich C, Kohler F, Bode V, Seibert E, Fiedler R, Girndt M. Monocytic angiotensin-converting enzyme 2 relates to atherosclerosis in patients with chronic kidney disease. Nephrol Dial Transplant. 2017; 32:287-98.

https://doi.org/10.1093/ndt/gfw206 PMID:28186543

80. Gilbert A, Liu J, Cheng G, An C, Deo K, Gorret AM, Qin $X$. A review of urinary angiotensin converting enzyme 2 in diabetes and diabetic nephropathy. Biochem Med (Zagreb). 2019; 29:010501.

https://doi.org/10.11613/BM.2019.010501 PMID:30591810

81. Chen D, Li X, Song Q, Hu C, Su F, Dai J, Ye Y, Huang J, Zhang $X$. Assessment of hypokalemia and clinical 
characteristics in patients with coronavirus disease 2019 in Wenzhou, China. JAMA Netw Open. 2020; 3:e2011122.

https://doi.org/10.1001/jamanetworkopen.2020.11122 PMID:32525548

82. Ackermann M, Verleden SE, Kuehnel M, Haverich A, Welte T, Laenger F, Vanstapel A, Werlein C, Stark H, Tzankov A, Li WW, Li VW, Mentzer SJ, Jonigk D. Pulmonary vascular endothelialitis, thrombosis, and angiogenesis in covid-19. N Engl J Med. 2020; 383:120-28.

https://doi.org/10.1056/NEJMoa2015432

PMID: 32437596

83. Licciardi F, Pruccoli G, Denina M, Parodi E, Taglietto M, Rosati S, Montin D. SARS-CoV-2-induced kawasaki-like hyperinflammatory syndrome: a novel COVID phenotype in children. Pediatrics. 2020; 146:e20201711.

https://doi.org/10.1542/peds.2020-1711 PMID: $\underline{2439816}$

84. Castelnovo L, Capelli F, Tamburello A, Faggioli PM, Mazzone A. Symmetric cutaneous vasculitis in COVID19 pneumonia. J Eur Acad Dermatol Venereol. 2020; 34:e362-63.

https://doi.org/10.1111/jdv.16589 PMID:32378747

85. Ebert T, Pawelzik SC, Witasp A, Arefin S, Hobson S, Kublickiene $K$, Shiels PG, Bäck $M$, Stenvinkel $P$. Inflammation and premature ageing in chronic kidney disease. Toxins (Basel). 2020; 12:227.

https://doi.org/10.3390/toxins12040227 PMID: $\underline{2260373}$

86. Noce A, Canale MP, Capria A, Rovella V, Tesauro M, Splendiani G, Annicchiarico-Petruzzelli M, Manzuoli M, Simonetti G, Di Daniele N. Coronary artery calcifications predict long term cardiovascular events in non diabetic Caucasian hemodialysis patients. Aging (Albany NY). 2015; 7:269-79. https://doi.org/10.18632/aging.100740 PMID:26131456

87. Donato AJ, Morgan RG, Walker AE, Lesniewski LA. Cellular and molecular biology of aging endothelial cells. J Mol Cell Cardiol. 2015; 89:122-35. https://doi.org/10.1016/i.yimcc.2015.01.021 PMID:25655936

88. Helms J, Kremer S, Merdji H, Clere-Jehl R, Schenck M, Kummerlen C, Collange O, Boulay C, Fafi-Kremer S, Ohana M, Anheim M, Meziani F. Neurologic features in severe SARS-CoV-2 infection. N Engl J Med. 2020; 382:2268-70.

https://doi.org/10.1056/NEJMc2008597 PMID:32294339

89. Moriguchi T, Harii N, Goto J, Harada D, Sugawara H, Takamino J, Ueno M, Sakata H, Kondo K, Myose N,
Nakao A, Takeda $M$, Haro $H$, et al. A first case of meningitis/encephalitis associated with SARScoronavirus-2. Int J Infect Dis. 2020; 94:55-58.

https://doi.org/10.1016/i.ijid.2020.03.062 PMID:32251791

90. Glass WG, Subbarao K, Murphy B, Murphy PM. Mechanisms of host defense following severe acute respiratory syndrome-coronavirus (SARS-CoV) pulmonary infection of mice. J Immunol. 2004; 173:4030-39.

https://doi.org/10.4049/jimmunol.173.6.4030 PMID:15356152

91. Netland J, Meyerholz DK, Moore S, Cassell M, Perlman S. Severe acute respiratory syndrome coronavirus infection causes neuronal death in the absence of encephalitis in mice transgenic for human ACE2. J Virol. 2008; 82:7264-75. https://doi.org/10.1128/JVI.00737-08 PMID:18495771

92. Liu H, Zhang X, Xiao J, Song M, Cao Y, Xiao H, Liu X. Astaxanthin attenuates $d$-galactose-induced brain aging in rats by ameliorating oxidative stress, mitochondrial dysfunction, and regulating metabolic markers. Food Funct. 2020; 11:4103-13. https://doi.org/10.1039/d0fo00633e PMID:32343758

93. Norden DM, Muccigrosso MM, Godbout JP. Microglial priming and enhanced reactivity to secondary insult in aging, and traumatic CNS injury, and neurodegenerative disease. Neuropharmacology. 2015; 96:29-41. https://doi.org/10.1016/j.neuropharm.2014.10.028 PMID:25445485

94. Liu CL, Shau WY, Wu CS, Lai MS. Angiotensinconverting enzyme inhibitor/angiotensin ॥ receptor blockers and pneumonia risk among stroke patients. J Hypertens. 2012; 30:2223-29. https://doi.org/10.1097/HJH.0b013e328357a87a PMID:22929610

95. Guzik TJ, Cosentino F. Epigenetics and immunometabolism in diabetes and aging. Antioxid Redox Signal. 2018; 29:257-74. https://doi.org/10.1089/ars.2017.7299 PMID:28891325

96. Yang JK, Lin SS, Ji XJ, Guo LM. Binding of SARS coronavirus to its receptor damages islets and causes acute diabetes. Acta Diabetol. 2010; 47:193-99. https://doi.org/10.1007/s00592-009-0109-4 PMID:19333547

97. Saban-Ruiz J, Ly-Pen D. COVID-19: a personalized cardiometabolic approach for reducing complications and costs. The role of aging beyond topics. J Nutr Health Aging. 2020; 24:550-59.

https://doi.org/10.1007/s12603-020-1385-5 PMID: $\underline{32510105}$ 
98. Rawshani A, Rawshani A, Franzén $\mathrm{S}$, Sattar $\mathrm{N}$, Eliasson $B$, Svensson AM, Zethelius B, Miftaraj M, McGuire DK, Rosengren A, Gudbjörnsdottir S. Risk factors, mortality, and cardiovascular outcomes in patients with type 2 diabetes. N Engl J Med. 2018; 379:633-44.

https://doi.org/10.1056/NEJMoa1800256

PMID:30110583

99. Kamide K, Rakugi H, Nagai M, Takiuchi S, Matsukawa N, Higaki J, Kawano Y, Ogihara T, Tuck ML. Insulinmediated regulation of the endothelial reninangiotensin system and vascular cell growth. J Hypertens. 2004; 22:121-27.

https://doi.org/10.1097/00004872-200401000-00021

PMID:15106803

100. Liu Y, Shi S, Gu Z, Du Y, Liu M, Yan S, Gao J, Li J, Shao Y, Zhong W, Chen X, Li C. Impaired autophagic function in rat islets with aging. Age (Dordr). 2013; 35:1531-44.

https://doi.org/10.1007/s11357-012-9456-0

PMID:22843415

101. Cesari M, Montero-Odasso M. COVID-19 and older adults. Lessons learned from the Italian epicenter. Can Geriatr J. 2020; 23:155-59. https://doi.org/10.5770/cgj.23.445

PMID:32550954

102. Epidemiology Working Group for NCIP Epidemic Response, Chinese Center for Disease Control and Prevention. [The epidemiological characteristics of an outbreak of 2019 novel coronavirus diseases (COVID19) in China]. Zhonghua Liu Xing Bing Xue Za Zhi. 2020; 41:145-51. https://doi.org/10.3760/cma.j.issn.02546450.2020.02.003 PMID: $\underline{32064853}$

103. Onder G, Rezza G, Brusaferro S. Case-fatality rate and characteristics of patients dying in relation to COVID19 in Italy. JAMA. 2020; 323:1775-76.

https://doi.org/10.1001/jama.2020.4683 PMID: 32203977

104. Shim E, Tariq A, Choi W, Lee Y, Chowell G. Transmission potential and severity of COVID-19 in South Korea. Int J Infect Dis. 2020; 93:339-44. https://doi.org/10.1016/j.ijid.2020.03.031 PMID: $\underline{32198088}$ 